\title{
粒状体におけるポテンシャル障壁，潜在 すべり面の概念の実験による考察*
}

\author{
北村 良 介**

\section{Experimental Consideration for Concepts of Potential Barriers and Potential Slip Plane in Particulate Materials}

by

\section{Ryosuke KITAMURA}

(Faculty of Engineering, Kagoshima University, Kagoshima)

In the previous paper, the author applied the Markov process to the deformation process of particulate materials and established a mechanical model of particulate materials. In the model the concepts of the potential barriers and the potential slip plane were introduced. These concepts represent the mechanical properties of particulate materials under deformation process at the particle scale.

In this paper, the experimental consideration is described in order to examine the validity of the concepts of the potential barriers and the potential slip plane. The sandy soils were poured into a water tank and deposited in a soil tank which was set at different sediment angles, $\theta=0^{\circ}$, $30^{\circ}, 60^{\circ}$ and $90^{\circ}$. Then, the specimens with different fabrics were prepared by sampling from the soil tank. The drained triaxial compression tests were performed under a constant confining pressure by using the saturated specimens with different initial fabrics.

The followings were made clear from the experimental results: the specimen with the sediment angle $\theta=0^{\circ}$ showed the greatest resistance to the deformation, the greatest strength and the most violent dilatancy; the specimen with the sediment angle $\theta=60^{\circ}$ showed the smallest resistance to the deformation, the smallest strength and the smallest dilatancy. These mechanical characteristics due to the different initial fabrics were qualitatively explainable by using the concepts of the potential barriers and the potential slip plane. This fact proves the validity of these concepts which were introduced in the mechanical model of particulate materials proposed by the author.

(Received June 26, 1981)

キー・ワード：粒状体，ポテンシャル障壁の概念，潜在すべり面の概念，三軸圧縮試験

\section{1 ま え がき}

地球表層部を構成している岩, 砂, 粘土のような地 盤材料の変形過程に括ける力学特性を解明するための 一方法として著者は物性論的立場に立ち, 確率過程の 一つであるマルコフ過程を適用して砂のような粒状体 に対する力学モデルの提案を行った. そのモデルでは 粒状体を構成する形状, 大きさが不規則な個々の粒子 の運動がマルコフ過程に従うものとみなされ，粒子レ ベルでの変形機構を解明するために確率論的考察が加 兄られた、モデルの確立に際し, 二つの新しい概念, すなわち，ポテンシャル障壁の概念，潜在すべり面の 概念が粒状体のせん断過程に導入された。これらの二

* 原稿受理 昭和 56 年 6 月 26 日

** 正会 員 鹿児島大学工学部 鹿児島市郡元
つの概念の妥当性は, 直接的には供試体内の粒子の運 動を観察することにより検証されるものであるが，変 形過程での供試体内の全粒子の運動を追求することは 不可能である. そこで，本論文では，間接的にこれら の概念の妥当性を検証している。すなわち, 初期粒子 構造の異る供試体を作製し，側圧一定条件下で排水三 軸圧縮試験を行い, 得られた変形特性の差異ボポテン シャル障壁の概念，潜在すべり面の概念を用いれば定 性的な説明が可能であることを明らかにしている。

2 ポテンシャル障壁の概念, 潜在すべり面の概念 ポテンシャル障壁の概念, 潜在すべり面の概念につ いてはすでに著者が粒状体の力学モデルを提案する際 に詳しい説明を行っているので，ここでは簡単にその 概略を述べるにとどめる. 


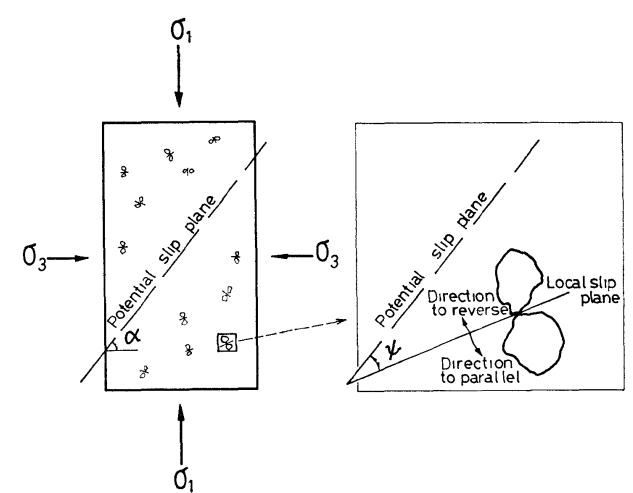

(a)

(b)
Fig. 1. Relation between potential slip plane and local slip plane.

Fig. 1 は通常の三軸試験に括ける円柱供試体 (Fig. 1(a)）とその供試体内に無数に存在する粒子接点の一 つをとり出したるの (Fig.1 (b)) を示している. (a)に 执いて， $\sigma_{1}, \sigma_{3}$ は各々最大, 最小主応力をあらわし ており， $\sigma_{1} \neq \sigma_{3}$ であるせん断過程においては図のよ らに潜在すべり面が存在する。潜在すべり面について は, すでに村山, 松岡・中井らが考察を行い, 潜在す べり面として村山は $(\tau / \sigma)_{\max }$ 一面を，また，松岡・ 中井は空間モービライズド面 (Spatial Mobilized Plane, 略して SMP) を提案している. Fig. 1 亿示 寸通常の三軸試験のような軸対称応力状態で, しかも， 鉛直方向が最大主応力となる場合には潜在ずべり面と 水平面とのなす角 $\alpha$ は各々次式のように規定される.

$(\tau / \sigma)_{\max }$ 一面の場合

$$
\alpha=45^{\circ}+\frac{1}{2} \varphi
$$

ここに,

$$
\varphi=\tan ^{-1}\left\{\frac{1}{2}\left(\sqrt{\sigma_{1} / \sigma_{3}}-\sqrt{\sigma_{3} / \sigma_{1}}\right)\right\}
$$

SMP の場合

$$
\alpha=\tan ^{-1} \sqrt{2 \sigma_{1} / \sigma_{3}}
$$

Fig. 1 亿示された潜在すべり面と供試体内に存在する 粒子接点で形成される局所的なすべり面とを関係づけ るために導入された新しい考方方がポテンシャル障壁 の概念と潜在すべり面の概念である.

Fig. 2 は粘弾性体の力学挙動を分子論的に説明する ためによく用いられる概念図であり, Fig. 3 は Fig. 2 に示された考方方を粒状体内の無数に存在する粒子接 点のうちの任意の 1 接点に適用した 3 次元的な図であ る. Fig. 3 飞和いて， $x_{\eta}$ はポテンシャル障壁の大き さをあらわしており， $x_{\eta, 1}, x_{\eta, 2}$ は各々ポテンシャル 障壁の最小值と最大值を示している。 また， $d \beta_{1}, d \beta_{2}$ は Fig. 4 亿示すように粒状体内の任意の 1 接点で形 成される接平面と規準座標軸とのな寸角（以下，接点 角と称する）の变化量をあらわしている. Fig. 3 によ

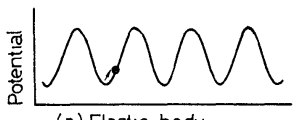

(a) Elastic body

产

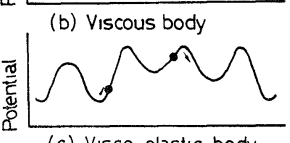

(c) Visco elastic body

Fig. 2. Concept of potential barriers.

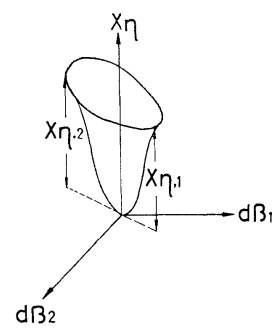

Fig. 3. Potential barrier at contact point.

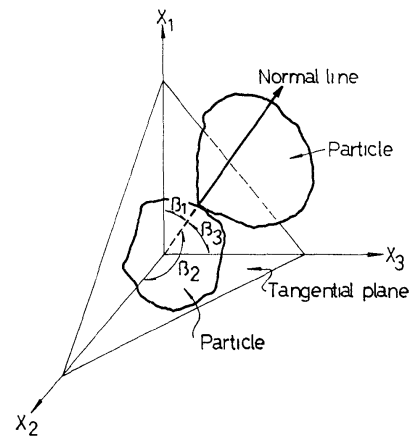

Fig. 4. Two adjacent particles and reference framé.

れば, 粒状体内の各接点に和いて, 接点角の変化関 するポテンシャル障壁が存在し, しかも, 接点間の変 化する方向によってポテンシャル障壁の大きさが異っ ていることがわかる。すなわち，ポテンシャル障壁が 最大である $x_{\eta, 2}$ 方向への接点角の変化は最も生じに くく，ポテンシャル障壁が最小である $x_{\eta, 1}$ 方向へは 最も変化しやすいことを意味している.このような粒 状体内の粒子の運動に関する仮説を粒状体に和けるポ テンシャル障壁の概念と称している.

つぎに潜在すべり面の概念について説明する，せん 断過程が進行するにつれて Fig. 1 (a) に示した供試体 は変形するが，そのことは，粒子のレベルでは供試体 内の任意の接点に扣いて Fig. 1 (b) に示すように，そ の局所的なすべり面が潜在すべり面の方向と一致しよ うとするか，㐫るいは逆の方向へ変化しょうとする粒 子の運動に対応している.潜在すべり面の概念とは, 
このよらな粒子の運動がランダムに生じるのではなく， ある一定の傾向をもって運動することをあらわす仮説 である、すなわちせん断過程に沶いて，粒状体内の任 意の接点の接点角が変化する際, Fig. 3 に示した接点 間の変化に関するポテンシャル障壁の大きさが最小で ある $x_{\eta, 1}$ の方向が潜在すべり面へ向ら方向と一致し, 最大である $x_{\eta, 2}$ の方向が潜在すべり面へ向ら方向と は逆になるといらことをあらわしている.これら二つ の概念, ポテンシャル障壁の概念および潜在すべり面 の概念をもとにせん断過程での粒状体の変形挙動を粒 子のレベルで確率論的にみると, 粒状体内に無数にあ る接点のらち, その接平面が潜在すべり面と一致しよ らとする変化 (Fig. 3 の $x_{\eta, 1}$ の方向への変化) を起 す接点の数は，逆の方向への変化 (Fig. 3 の $x_{\eta, 2}$ の 万向への変化）を起す接点の数より多いということに なる.

\section{3 三軸圧縮試験および結果の考察}

\section{$3 \cdot 1$ 試料および試験方法}

前述の二つの概念の妥当性を検証するために, 豊浦 標準砂执よびシラスを用い, 初期粒子構造の異る供試 体を作製し，側圧一定条件下で排水三軸圧縮試験を行 った. シラスは鹿児島市内で採取したもので，840 ふるいを通過し， $74 \mu$ ふるいに残留する部分を用いた. 初期粒子構造の異る供試体は Fig. 5 に示される水槽 および土槽を用いて次のような手順で作製された。 ず, Fig. 5 (a) に示すように, 縦 $75 \mathrm{~cm}$, 横 $95 \mathrm{~cm}$, 奥行き $30 \mathrm{~cm}$ の水槽に縦 $20 \mathrm{~cm}$, 横 $40 \mathrm{~cm}$, 奥行き

(a)

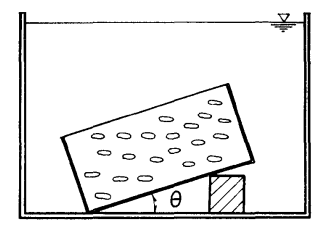

(b)

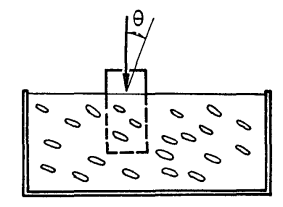

Fig. 5. Preparation of specimen.
$8.7 \mathrm{~cm}$ の土槽を所定の傾斜角度 $\theta$ になるよらに設置 し, 飽和した試料を静かに水中落下させ, 土槽に堆積 させた. 土槽の傾斜角度 $\theta$ は $0^{\circ} よ り ~ 90^{\circ}$ まで $30^{\circ}$ お きに 4 種類とした. 土槽に堆積した試料は, Fig. 5 (b) に示すように土槽中にサンプリングモールドを挿入す ることにより採取し，そのまま凍結させた，供試体の 大きさは直径 $5 \mathrm{~cm}$, 高さ $12 \mathrm{~cm}$ である. Fig. 6 はこ のような手順で作製された供試体の初期粒子構造の差 異を模式的に示したものである. 土粒子を水平落下に より土槽に堆積させた場合には土粒子の長軸方向が水
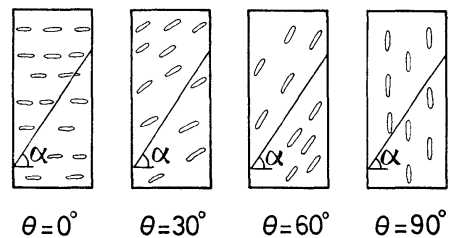

Fig. 6. Specimens possessing different initial fabrics.

平になるように堆積するものが多く, 土槽の傾斜角度 を変化させることにより Fig. 6 と示すような初期粒 子構造の異る供試体が作製されるものと考光られる. このようにして得られた豊浦標準砂, シラスの供試体 の初期間げき比が Table I に示されている. Table I の值には多少のばらつきはあるが，両試料を用いて作 製された供試体はそれぞれ比較的緩い，ほぼ同一の初 期間げき比を有するものとみなすことができる。モー ルドから取り出された供試体はすばやく直径と高さが 測定され，三軸装置にセットされた。そして, 約 100 分間, 所定の圧力 $\left(100 \mathrm{kN} / \mathrm{m}^{2}\right)$ で等方圧縮しながら 融解させた。圧縮試験は側圧一定 $\left(100 \mathrm{kN} / \mathrm{m}^{2}\right)$, 排水 条件のもとでひずみ制御型で行った，せん断速度は軸 ひずみ速度 $0.8 \% /$ 分である.

\section{$3 \cdot 2$ 実験結果および考察}

Fig. 7，8 はそれぞれ豊浦標準砂，シラスを用いた 4 種の初期粒子構造の異る供試体で得られた応力〜ひ ずみ〜体積変化関係も示したるのである. 図に抒いて, $\sigma_{1}, \sigma_{3}$ は最大拉よび最小主応力， $\varepsilon_{1}$ は軸ひずみ， $\varepsilon_{v}$ は体積ひずみをあらわしている，また，ひずみは压縮

Table I. Values of initial void ratio $e_{0}$, internal friction angle $\phi$ and $\alpha$.

\begin{tabular}{|c|c|c|c|c|c|c|c|c|}
\hline \multirow[b]{2}{*}{$\theta^{\circ}$} & \multicolumn{4}{|c|}{ Toyoura standard sand } & \multicolumn{4}{|c|}{ Shirasu } \\
\hline & $e_{0}$ & $\phi^{\circ}$ & $\begin{array}{l}\alpha^{\circ}\left((\tau / \sigma) \text { max }^{-}\right. \\
\text {plane })\end{array}$ & $\alpha^{\circ}(\mathrm{SMP})$ & $e_{0}$ & $\phi^{\circ}$ & $\begin{array}{l}\alpha^{\circ}\left((\tau / \sigma)_{\max }^{-}\right. \\
\text {plane })\end{array}$ & $\alpha^{\circ}(\mathrm{SMP})$ \\
\hline 0 & 0.79 & 37.6 & 63.8 & 70.8 & 1.30 & 43.5 & 66.7 & 73.1 \\
\hline 30 & 0.79 & 36.8 & 634 & 70.5 & 1.27 & 41.7 & 65.8 & 72.4 \\
\hline 60 & 0.79 & 33.8 & 61.9 & 69.3 & 1.27 & 39.1 & 646 & 71.4 \\
\hline 90 & 073 & 36.0 & 63.0 & 70.2 & 1.37 & 40.3 & 65.1 & 71.9 \\
\hline
\end{tabular}




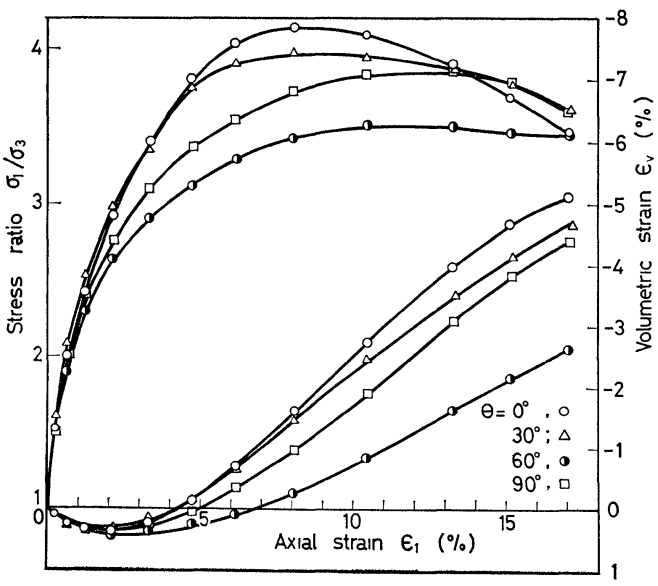

Fig. 7. Relationships between stress, axial strain and volumetric strain for Toyoura standard soil.

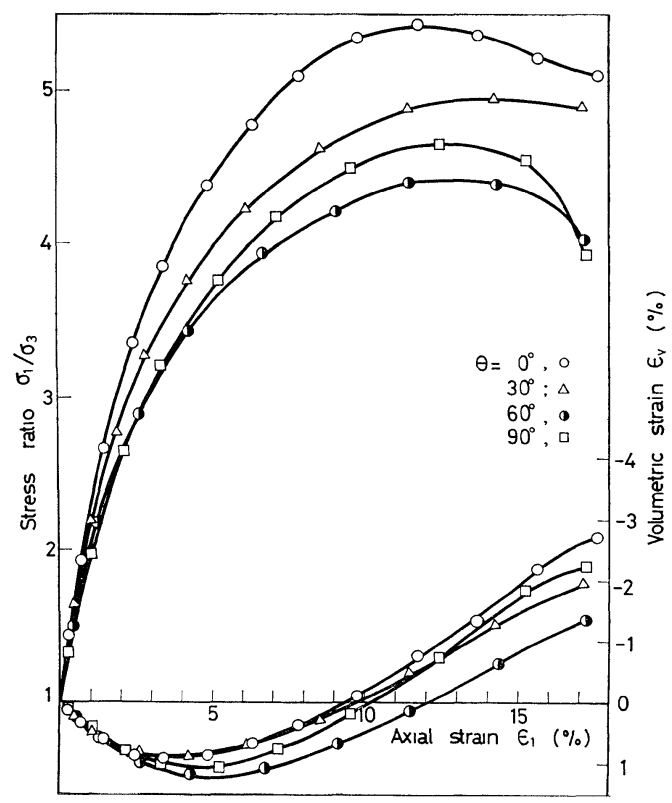

Fig. 8. Relationships between stress, axial strain and volumetric strain for Shirasu.

を正にとっている. Fig. 7，8 と和いて応力〜軸ひず み曲線は, 豊浦標準砂の場合もシラスの場合も傾斜角 度 $\theta=60^{\circ}$ の供試体の曲線がピーク強度付近までの変 形過程では常に最も下にあり, 傾斜角度 $\theta=0^{\circ}$ の供 試体の曲線が常に最も上にきている。 そして, 傾斜角 度 $\theta=30^{\circ}$ と $90^{\circ}$ の曲線がそれらの間に入ってきてい る.すなわち, 同じ軸ひずみに対して応力比は傾斜角 度 $\theta=60^{\circ}, 90^{\circ}, 30^{\circ}, 0^{\circ}$ の順に大きくなっているこ とがわかる. Table I には各供試体のピーク強度より 計算された内部摩擦角 $\phi か ゙$ 示されている. 表より豊浦 標準砂の場合もシラスの場合にもともに傾斜角度 $\theta=$ $60^{\circ}$ の供試体の内部摩擦角が最小で, $90^{\circ}, 30^{\circ}, 0^{\circ}$ の
順に大きくなっていることがわかる。これらの結果よ り試料の区別なく傾斜角度 $\theta=60^{\circ}$ の供試体が最も変 形しやすく, 強度も最も小さいこと， $\theta=90^{\circ}, 30^{\circ}$ の 順に変形しにくくなり, 強度も大きくなること, そし て $\theta=0^{\circ}$ の供試体が最も変形しにくく, 強度も最も 大きいことがわかる.Fig.7，8 に示された軸ひずみ 〜体積ひずみ曲線においても応力〜軸ひずみ曲線の場 合と同様な傾向がみられる.すなわち, 軸ひずみが 1 \%付近までは明りょうな差異がないが，それ以後の変 形段階においては, 試料の区別なく傾斜角度 $\theta=0^{\circ}$ の供試体より得られた軸ひずみ〜体積ひずみ曲線が常 に最も上にあり, $\theta=60^{\circ}$ の供試体の曲線が最も下に きて扣り， $\theta=30^{\circ}, 90^{\circ}$ の供試体の曲線がそれらの間 と描かれている.このことは, 傾斜角度 $\theta=0^{\circ}$ の供 試体のせん断過程での体積変化, すなわち, ダイレイ タンシー量が最も大きく, $\theta=30^{\circ}, 90^{\circ}$ と続き， $\theta=$ $60^{\circ}$ の供試体のダイレイタンシー量が最も小さいこと をあらわしている。このようなダイレイタンシー挙動 の差異を粒子レベルで考えると, 傾斜角度 $\theta=0^{\circ}$ の 供試体では, その中に含まれる粒子の運動が最も激し く, $\theta=60^{\circ}$ の供試体では最も小さいことを意味して いるものと考兄られる.

Table I に示すょらにほぼ同一の初期間げき比を有 寸る供試体を用い, 同一条件下で三軸圧縮試験を行い, 得られた応力〜軸ひずみ〜体積変化関係に上述のよう な差異が生じたのは供試体の初期粒子構造の差異によ るものとみなすことができる.ここでは，これらの力 学特性の差異を定性的に説明するために, 2 節で述べ たポテンシャル障壁の概念, 潜在すべり面の概念を用 いて供試体内の粒子の運動について考察を加觉ること にする. せん断過程に拈いて, 供試体内に無数に存在 する接平面は粒子相互の運動によって変化するが，そ のとさ, ポテンシャル障壁の概念, 潜在すべり面の概 念を用いれば, 各接点に批いてポテンシャル障壁が存 在し, 接点角の变化関しては, 接平面が潜在すべり 面と一致しょうとする変化確率の方が逆の方向への変 化確率よりも大きいことになる.ところで, Fig.1 (b) に示されるように潜在すべり面と供試体内のある接点 での接平面（局所的なすべり面）とのなす角をせとす れば, 『が小さい程, 潜在すべり面と接平面が一致す

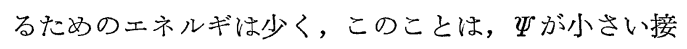
点では Fig. 3 に示したポテンシャル障壁の大ささの 最小值 $x_{\eta, 1}$ が， $\Psi$ が大きい接点でのそれよりも小さ く，粒子接点での運動が容易であることを意味してい

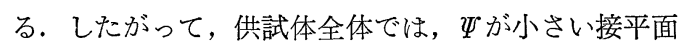
の数が多いほど变形しやすく, また, 粒子相互ののり あがりなどを反映したダイレイタンシー量も小さくな るものと考光られる. 
ところで, 2 節で述べた $(\tau / \sigma)_{\max }$ 一面あるいはSMP を潜在すべり面とすれば，(1)，(2)，(3)式とみればわか るように，せん断過程が進み，主応力比 $\sigma_{1} / \sigma_{3}$ が増 加するにつれて Fig. 1 飞示した潜在すべり面と水平 面のなす角 $\alpha$ は変化していく. Fig.7，8 亿示された 応力〜軸ひずみ曲線に招けるピーク強度時の $\sigma_{1} / \sigma_{3}$ の 值を(1)，(2)式あるいは(3)式に代入すると潜在すべり面 として $(\tau / \sigma)_{\max }$ 一面あるいはSMPを用いた場合のピ 一ク強度時の $\alpha$ が計算でき，それらの值が Table I に示されている．表をみればわかるように，等方圧縮

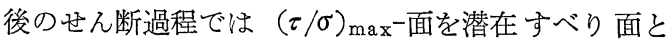
すれば，豊浦標準砂に対しては $\alpha$ は $45^{\circ}$ から $61.9^{\circ} \sim$ $63.8^{\circ}$ まで変化し, シラスに対しては $45^{\circ}$ から $64.6^{\circ}$ 〜66. $7^{\circ}$ まで変化する. また，SMP を潜在すべり面 とすれば，豊浦標準砂に対しては $\alpha$ は $54.7^{\circ}$ から $69.3^{\circ} \sim 70.8^{\circ}$ まで変化し，シラスに対しては $54.7^{\circ}$ から $71.4^{\circ} \sim 73.1^{\circ}$ まで変化する. $\alpha$ がこのような值 をとることと Fig. 6 の初期粒子構造 の 差異を示した 模式図より，変形過程中に潜在すべり面之供試体内の 接平面とのなす角 $\Psi$ が小い接点が最も多い供試体は 傾斜角度 $\theta=60^{\circ}$ のものであり, 最も少い供試体は $\theta$ $=0^{\circ}$ のものであり, $\theta=30^{\circ}$ と $90^{\circ}$ の供試体はその 間に入ることがわかる. $\theta=30^{\circ}$ と $90^{\circ}$ の供試体につ いては, せ九断過程の初期段階では $\theta=30^{\circ}$ のものの 方が $\theta=90^{\circ}$ のものより $\Psi$ 小さい接点が多いが，ピ 一ク強度付近では逆に $\theta=90^{\circ}$ のものの方が $\Psi$ 小さ い接点が多くなるものと考觉られる.

ポテンシャル障壁の概念, 潜在すべり面の概念を用 いたこれまでの考察より潜在すべり面と粒子接平面と のなす角 $\Psi$ がさい接点が最も多いと考兄られる傾斜 角度 $\theta=60^{\circ}$ の供試体が最も変形しやすく, 強度も最 も小さく, ダイレイタンシー量も最も小さく, $\theta=90^{\circ}$, $30^{\circ}$ の順に変形しにくく, 強度も大きく, ダイレイタ ンシー量も大きくなること, そして， $\theta=0^{\circ}$ の供試体 が最も変形しにくく, 強度も最も大きく, ダイレイタ ンシー量も最も激しくなることがわかる。すなおち， 従来から指摘されてきて怙り，本論文に执いてもFig. 7,8 亿示されている初期粒子構造の差異によるせん 断過程での力学特性の差異は, ポテンシャル障壁の概 念, 潜在すべり面の概念を用いた粒子レベルでの考察 によっても定性的沉説明できたわけである。このこと は, 著者が提案しているこれらの二つの概念が妥当で あることを明らかにしている。

\section{4 あとがき}

豊浦標準砂とシラスを用い, それぞれ注涪同一の初 期間げき比を有するが，初期粒子構造の異る 4 種の供 試体を作製し，側圧一定，排水三軸圧縮試験を行った。 その結果, 試料を堆積させる傾斜角度 $\theta=60^{\circ}$ の供試 体が最も変形しやすく, 強度も最も小さく, ダイレイ タンシー量も最も小さいこと, $\theta=90^{\circ}, 30^{\circ}$ の順に変 形しにくくなり, 強度も大きくなり, ダイレイタンシ 一量も大きくなること, $\theta=0^{\circ}$ の供試体が最も変形し にくく, 強度も最も大きく, ダイレイタンシー量も最 も激しいことがわかった。これらの実験事実は，著者 が提案しているマルコフ過程を用いた粒状体の力学モ デルの中で導入されたポテンシャル障壁の概念, 潜在 すべり面の概念を用いた粒子レベルでの考察によって も定性的な説明が可能であり, このことは, 逆に, こ れらの二つの概念が妥当であることを示している.

最後に, 本研究は著者が京都大学在籍中に村山朔郎 名誉教授, 赤井浩一教授のご指導のもとに行った研究 の一部を発展させたるのであり,このような研究の機 会を与兄ていただいた両先生に感謝の意を表します。 また, 本研究遂行にあたり援助, 助言をいただいた本 学の春山教授, 卒論研究として実験をともにしてくれ た小林弘樹氏に感謝いたします。な拈，本研究は昭和 55 年度科学研究費（奨励研究 $\mathrm{A}$ ) 飞よるものの一部で ある。

\section{参 考 文 献}

1) 北村良介, 材料, 28, 718 (1979).

2) Kitamura, R., S \& F, 21, 2, 63 (1981).

3) Kitamura, R., S \& F, 21, 2, 85 (1981).

4) Murayama, S., Proc. IUTAM Sympo. on Rheology and Soil Mech., 146(1964).

5) Murayama, S., Proc. Specialty Session 9,9 th ICSMFE, 167 (1977).

6) Matsuoka, H., and T. Nakai, Proc. JSCE, 232, 59 (1974).

7）向坊 隆編，基礎工学，13（1968）岩波書店

8) Oda, M., I. Koishikawa, and T. Higuchi, S \& F, 18, 1, 25 (1978).

9) Yamada, Y., and K. Ishihara, S \& F, 19, 2, 79 (1979).

10）足立紀尚，林 正之， 土木学会論文報告集， 305, 97 (1981). 